\title{
MANAJEMEN KONFLIK KEAGAMAAN MELALUI JARINGAN KERJA ANTAR UMAT BERAGAMA DI BANDUNG JAWA BARAT
}

\section{The Religious Conflict Management Through Network of Inter Religious Communities in Bandung, West Java}

\author{
Anik Farida \\ Balai Penelitian dan Pengembangan Agama \\ Jl. Rawakuning no 6 Pulogebang Cakung Jakarta Timur \\ Email: anik_farida@yahoo.co.id
}

Naskah diterima tanggal 28 Mei 2014. Naskah direvisi tanggal 15 Februari 2015. Naskah disetujui tanggal 22 Mei 2015

\begin{abstract}
Abstrak
Konflik sosial keagamaan di Indonesia tidak seluruhnya berakhir dengan kekerasan. Kenyataan ini hendaknya dibaca dari sudut pandang bahwa masyarakat, atau kelompok masyarakat Indonesia sesungguhnya memiliki kapasitas untuk merespons berbagai isu konflik keagamaan melalui cara-cara damai. Penelitian ini memperlihatkan salah satu kelompok masyarakat yang memiliki kapasitas untuk melakukan upaya pencegahan dengan cara merevitalisasi pranata sosial budaya yang merupakan unsur kultural yang hidup dan tumbuh di masyarakat, seperti dicontohkan oleh komunitas Jakatarub. Penelitian dilakukan dengan metode wawancara, observasi, telaah dokumen dan diskusi kelompok terfokus. Penelitian ini menyimpulkan bahwa, Jakatarub menjadi simpul bagi bertemunya berbagai kelompok agama, tradisi, dan kelompok sosial yang berbeda untuk melakukan dialog, merayakan perbedaan dan mengkampanyekan pentingnya sikap toleransi di Bandung secara khusus dan umumnya di wilayah Jawa Barat. Dalam kiprahnya jaringan ini sudah menyelenggarakan berbagai acara dalam rangka mewujudkan masyarakat yang menghargai perbedaan. Dengan cara inilah Jakatarub telah mengelola potensi konflik di masyarakat agar tidak berkembang menjadi kekerasan keagamaan.
\end{abstract}

Kata kunci: konflik sosial keagamaan, jejaring antar warga, manajemen konflik, Bandung.

\begin{abstract}
Socio-religious conflicts in Indonesia are not entirely ended in violence. This fact should be read from the point of view that the Indonesian society, or group of society, actually have the capacity to respond to the issues of religious conflict through peaceful means. This study shows one group of society who has the capacity to undertake prevention efforts by revitalizing the socio-cultural institutions that are cultural elements living and growing in community, as exampled by the Jakatarub community. The research was conducted through interviews, observations, review of documents and group disscusion focused. This research concluded that Jakatarub became a node for convergence of various religious groups, traditions, and different social groups to engage in dialogue, to celebrate differences and to promote the importances of tolerance in Bandung in specific and in West Java in general. In its role, this network has been organizing various events in order to create a society that respects difference. Through this, Jakatarub has managed the potential conflicts in society in order not to develop religious violence.
\end{abstract}

Keywords: social religious conflict, civics' network, conflict management, Bandung. 


\section{PENDAHULUAN}

$\mathrm{K}$ onflik, tidak selamanya harus dimaknai sebagai kejadian sosial yang bersifat destruktif, karena hasil penelitian Balai Litbang Agama Jakarta tahun 2008, tentang 'Pola Konflik Sosial Keagamaan di Indonesia, dan kemudian diperkuat oleh hasil penelitian yang dilakukan oleh Yayasan Paramadina tahun 2009, memperlihatkan adanya fungsi konstruktif dari konflik, yakni melahirkan sejumlah perubahan sosial ke arah yang positif. Ada temuan menarik yang dihasilkan dari penelitian itu. Dari total 444 insiden konflik keagamaan yang terjadi dalam kurun 2004-2007 di 10 provinsi tersebut, sekitar 83\% (368) insiden terwujud dalam bentuk aksi damai, sementara $17 \%$ (76) lainnya dalam bentuk insiden kekerasan (Farida dkk., 2008). Temuan itu hendaknya dibaca dari sudut pandang bahwa masyarakat Indonesia sesungguhnya memiliki kapasitas untuk merespons berbagai isu konflik keagamaan melalui cara-cara damai.

Terkait dengan temuan di atas, maka pertanyaan selanjutnya adalah mengapa tidak semua insiden/konflik keagamaan berakhir/disertai dengan kekerasan?. Apakah variasi ini terkait dengan faktor-faktor budaya, religiusitas, demografi, sosialekonomi, masyarakat sipil (civil society), ataukah terkait dengan faktor kelembagaan, seperti kapasitas pemerintah daerah, termasuk institusi keamanan, dalam mengelola konflik keagamaan?. Faktor-faktor non keagamaan ini diasumsikan memberikan sumbangan penting bagi pilar toleransi beragama, dan akhirnya akan memberikan dukungan bagi terciptanya kerukunan umat beragama. Dengan kata lain, konflik sosial keagamaan telah melahirkan inisiasi konstruktif berupa instrumen fungsional untuk mencegah konflik, bahkan menstransformasi konflik. Misalnya, dengan lahirnya sejumlah regulasi yang mengatur kerukunan umat beragama, seperti Peraturan Bersama Menteri (PBM No. 9 dan 8 Tahun 2006 Tentang Pendirian Rumah Ibadat), upaya untuk merevitalisasi kearifan lokal untuk kerukunan, berdirinya forum-forum lintas agama seperti Forum Kerukunan Umat Beragama (FKUB), dan sebagainya.

Bertolok dari berbagai masalah, kenyataan dan harapan seperti diuraikan di atas, maka penelitian tentang bagaimana kapasitas masyarakat menangani konflik sosial agama merupakan sebuah studi yang sangat penting. Penelitian ini telah membawa perspektif baru dalam mengkaji fenomena konflik keagamaan, di mana aspek damai dan kekerasan menjadi bagian integral dari fokus studi yang dilakukan. Dengan kata lain, penelitian itu berpijak pada asumsi bahwa fenomena kekerasan tidak dapat dipisahkan, dan karena itu hendaknya tidak dikaji secara terpisah dari fenomena aksi damai: kita tidak dapat memahami mengapa suatu wilayah cenderung diterpa aksi kekerasan, tanpa kita memahami mengapa di wilayah lain konflik dapat berwujud dalam aksi damai.

Salah satu elemen yang memiliki kapasitas untuk mengelola konflik adalah masyarakat. Pada elemen masyarakat, upaya pencegahan dilakukan dengan merevitalisasi pranata sosial budaya yang merupakan unsur kultural yang hidup dan tumbuh di masyarakat. Kearifan lokal bersifat tidak memaksa, tetapi merupakan unsur kultural yang ada dan hidup di dalam masyarakat, maka daya ikatnya pun lebih mengena dan bertahan dibandingkan dengan pemaksaan sebuah sistem nilai dari luar. Dengan demikian kearifan lokal ini merupakan modal sosial yang sifatnya genuine ketika digunakan sebagai pranata pencegahan konflik, yang dapat menghadirkan perdamaian sebagai collectivness consciousness.

\section{Tinjauan Pustaka}

Strategisnya budaya lokal dalam penyelesaian konflik juga dapat dianalisa dalam kasus konflik di Bali sebagaimana dijelaskan dalam penelitian Wayan Rai (2011: 2-11) berjudul Manajemen Konflik Sosial di Bali. Dalam penelitian tersebut dijelaskan bahwa penyelesaian konflik antar sesama Hindu maupun lintas agama, dilakukan dengan menggunakan media desa-desa pakraman untuk terjadinya mediasi. Dalam media desa adat seperti itu terdapat kearifan lokal berupa konsep tri hita karana; semboyan desakala-patra, linggih manut sasana, sasana manut linggih; juga doktrin swadarma.

Kajian tentang penggunaan kearifan lokal dalam resolusi konflik dilakukan diantaranya oleh John Haba sebagaimana dikutip oleh Alpha Amirrachman (2007). Haba dalam studinya melihat lima peran vital kearifan lokal sebagai media resolusi konflik keagamaan, yang terjadi di Poso. Peran tersebut diantaranya: penanda identitas, aspek kohesif, mekanisme hukum, mendorong terbangunnya kebersamaan, mengubah pola pikir 
dan hubungan timbal balik individu dan kelompok, dengan meletakkan di atas kebudayaan yang dimiliki. Mengenai kearifan lokal menyediakan aspek kohesif berupa elemen perekat lintas agama, lintas warga, dan kepercayaan juga ditunjukkan dengan konsep civic network atau jejaring warga dalam studi yang dilakukan Varshney (2009) di India.

\section{METODE PENELITIAN}

Penelitian ini dilakukan di Kota Bandung. Kota Bandung sebagai ibukota Jawa Barat tercatat beberapa kali terjadi konflik keagamaan seperti perebutan lahan lokasi Sekolah Menengah Atas Kristen (SMAK) di daerah Dago, konflik antar jemaah gereja Pendeta Hadasah di Gereja Tabernakel dan juga konflik yang berlatarbelakang munculnya aliran sesat. Namun konflik-konflik tersebut, tidak menjadi konflik yang besar dan dapat diselesaikan secara internal melalui komunitas masing-masing kelompok bersangkutan atau atas mediasi penduduk lokal.

Meski dengan potensi konflik yang hampir sama seperti pada masyarakat urban lain, namun sejauh ini potensi konflik di Bandung dapat dikelola dengan baik oleh masyarakat. Potensi konflik seperti komposisi penduduk yang heterogen, baik etnis maupun kelompok agama, lahan ekonomi yang juga terbatas, serta jumlah penduduk yang besar, justru tidak menjadi sumber konflik. Heterogenitas tersebut malah menjadi modal bagi bertumbuhnya beberapa komunitas yang memiliki perhatian dan kepedulian pada pengembangan nilai-nilai toleransi, pluralisme, perdamaian dan kerjasama antar komunitas. Komunitas-komunitas tersebut berperan aktif dalam menjaga stabilitas dan komunikasi antar kelompok yang heterogen tersebut. Bermunculannya kelompok seperti itu menjadi penyeimbang di tengah berkembangnya ormas-ormas radikal yang juga cukup subur tumbuh di tengah masyarakat Jawa Barat dan Bandung secara khusus.

Sebagian komunitas yang peduli pada pengelolaan konflik dan perdamaian melandasakan program dan ideologi gerakannya pada nilainilai universal seperti perdamaian, hak asasi manusia, pluralisme dan persaudaraan. Di antara komunitas tersebut misalnya ada INCRES dan Peace Generation. Selain itu ada juga kelompok yang mengkampanyekan nilai toleransi dan perdamaian yang berbasiskan pada teologi dan kebudayaan seperti yang dilakukan oleh keluarga besar Jaringan Kerja Antar Umat Beragama atau dikenal dengan Jakatarub.

Penelitian ini terfokus pada komunitas Jakatarub, yang bersifat studi kasus, sehingga pendekatan yang digunakan adalah kualitatif. Data digali dengan metode wawancara, studi dokumen dan focus group discussion (FGD). Wawancara untuk mendapatkan data tentang potensi rawan konflik dilakukan pada pihak kepolisian, tokoh agama dalam kepengurusan MUI kota Bandung dan Provinsi Jabar, Kepala Kesbanglinmas, pengurus FKUB, Pengurus Jakatarub.

\section{PEMBAHASAN \\ Potensi Konflik Bernuansa Keagamaan di Bandung, Jawa Barat}

Beberapa lembaga riset menempatkan Jawa Barat sebagai wilayah dengan tingkat intoleransi keberagamaan tertinggi di Indonesia pada lima tahun terakhir. Hasil riset tersebut menggambarkan betapa wilayah ini sangat rentan terjadi konflik. Data terbaru disampaikan dalam Laporan Kehidupan Beragama tahun 2013 oleh Center for Religious and Cross Culture Studies (CRCS) Universitas Gadjah Mada yang dipublikasikan pada Kamis, 25 April 2013.

Fakta tentang angka kekerasan tersebut dapat dijelaskan dengan melihat dua aspek berikut: pertama, aspek historis dimana terdapat peristiwa konflik keagamaan di Jawa Barat. Kedua, terjadinya perubahan sosial kontemporer yang terjadi di wilayah ini.

Secara historis ada beberapa peristiwa konflik bernuansa agama di Jawa Barat, baik vertikal antara negara dengan masyarakat, maupun horisontal yang melibatkan sesama kelompok masyarakat. Martin van Bruinessen (2002: 117-154) menyebutkan dua hal yang menjadi akar munculnya radikalisme di Indonesia. Pertama, sejarah Darul Islam dan partai Masyumi. Kedua, adanya Jaringan Islam Transnasional.

Sejarah DI/TII diyakini tetap memiliki kontribusi ideologis pada tindak kekerasan yang terjadi akhir-akhir ini. Pada peristiwa kontemporer, ada yang melihat pengaruh DI/ TII ini muncul kembali dan ramai menjadi isu nasional melalui gerakan NII yang berkembang di tengah-tengah masyarakat. Gerakan ini dianggap sebagai lanjutan dari ideologi DI/TII yang kini bermetamorfosis menjadi KW 9 dan secara 
kelembagaan dikembangkan di Pesantren AlZaytun, sebagaimana dilaporkan oleh INSEP (2007). Kemunculan gerakan ini banyak dikaitkan dengan beberapa kasus penculikan, kasus pencucian otak dan rekruitmen yang terjadi di kalangan mahasiswa.

Kartusuwiryo historis telah lama meninggal, namun Kartosuwiryo simbolis diyakini masih tetap hidup dan menebar daya pikat bagi sekelompok orang yang selalu berkeinginan mendirikan negara di luar haluan yang telah diikrarkan para penidiri bangsa. Ini juga salah satu akar intoleransi tersembunyi itu. Sejarah itu mencatat bahwa dalam memperjuangkan keinginannya, DI/TII jelas menggunakan kekerasan. Untuk memenuhi kebutuhan logistiknya mereka mengoperasikan teror kepada penduduk setempat seperti simpul diksi yang ditahbiskan kepada mereka sebagai gerombolan. Tidak aneh juga apabila DI pun diplesetkan menjadi Duruk Imah (Darba, A Adaby, 2007).

Hasrat untuk mendirikan negara Islam sebagaimana dulu dirintis oleh gerakan DI/TII sepertinya tidak pernah redup. Hal itu dapat dilihat pada lahirnya beberapa Peraturan Daerah Syariah dan juga menguatnya kelompok Islam fundamentalis di wilayah ini yang memiliki benang merah dengan sejarah DI/TII. Bagi sebagaian penduduk di wilayah Priangan ideologi DI/TII menjadi warisan turuntemurun dari kakek dan orang tua mereka. Spirit tersebut tetap terpelihara pada beberapa organisasi keagamaan seperti Syarikat Islam dan Partai Syarikat Islam Indonesia (PSII), juga tetap menjadi bagian dalam proses belajar-mengajar di beberapa pondok pesantren dan madrasah di wilayah Jawa Barat.

Tingginya intoleransi di Jawa Barat juga dapat dipahami dari perubahan sosial yang terjadi di wilayah ini. Perubahan signifikan terjadi pasca runtuhnya orde baru dimana kemudian berbagai aspek dalam kehidupan berbangsa mengalami perubahan. Misalnya adanya demokratisasi pada berbagai bidang kehidupan, seperti sentralisasi menjadi desentralisasi pemerintah dan semakin terbuka lebar ruang bagi aspirasi masyarakat. Pada ruang ekspresi yang terbuka tadi berbagai kelompok sosial keagamaan bermunculan seperti jamur di musim penghujan.

Reformasi juga menjadi momentum bagi berbagai kelompok dalam masyarakat untuk saling bernegosiasi kembali dalam menemukan pola-pola relasi baru. Banyak kelompok sosial, kebudayaan dan keagamaan yang semula subaltern, maka pada periode ini tampil ke publik dengan identitasnya masing-masing. Kelompok keagamaan seperti Ahmadiyah dan kelompok agama minoritas yang berbasis pada nilai agama lokal menjadi relatif lebih leluasa dalam menjalankan aktivitasnya. Gejala ini dianggap baru dalam pengertian semula kelompokkelompok agama minoritas, apalagi kelompok agama lokal tidak mendapat ruang dalam kehidupan masyarakat di masa Orde Baru.

Kemunculan kelompok-kelompok sosial dan keagamaan baru tersebut mendapat respon dari kelompok agama mainstream yang sebelumnya sudah dulu eksis dan berkiprah dalam kehidupan masyarakat. Pertemuan antara kelompok sosial dan keagamaan baru dengan ormas keagamaan masintream memunculkan kompetisi dalam perebutan ruang sosial, klaim kebenaran dan perebutan posisi politik.

Dalam kondisi seperti itu, maka perubahan sosial ini menjadi potensi bagi munculnya konflik keagamaan dalam masyarakat. Artinya bahwa kemunculan kelompok agama baru menjadi salah satu pemicu terjadinya konflik horisontal bernuansa agama di Jawa Barat.

Konflik keagamaan yang dilatarbelakangi kemunculan ajaran keagaman baru tidak hanya melibatkan komunitas keagamaan tetapi juga aktor negara seperti pemerintah daerah. Hal ini dapat dilihat pada ditetapkannya beberapa peraturan daerah (Perda) dan Peraturan Gubernur yang melarang kegiatan dan eksistensi kelompok keagamaan tertentu di wilayah administratifnya.

Untuk wilayah Jawa Barat jumlah kasus kemunculan aliran keagamaan baru yang kemudian di anggap sesat sangat tinggi. Dalam data yang dikeluarkan FUUI pada 2007 kemunculan aliran sesat mencapai angka 250, dengan 50 kelompok diantaranya berkembang di Jawa Barat. Kemunculan kelompok ini menjadi pemicu konflik antar kelompok agama. Di Indonesia kemunculan aliran agama (religious subculture) kerap memicu konflik internal antar penganut agama (conflict from within). Selama rentang tahun 2003-2004 saja tercatat hampir tiga belas peristiwa konflik antar pemeluk agama yang dilatari kemunculan sekte, mazhab atau aliran agama. Misalnya konflik komunitas Eden, aliran Abah Ended di Serang, Sekte Hari Kiamat, dan Al Qiyadah Al Islamiyah.

Kasus yang sama juga terjadi dalam komunitas 
agama Kristen. Empat kasus konflik intern Kristen yang menyita peratian publik di Jawa Barat adalah konflik perebutan gereja dikalangan internal HKBP di jl. Riau pada 2007, HKBP di Ciketing Bekasi, penyesatan pendeta Hadassah pimpinan gereja Bethel di Jl. Lengkong, serta konflik di SMAK Dago (Farida, Anik, 2012).

Kemunculan satu konflik juga memiliki pengaruh pada munculnya konflik baru. Misalnya dalam kasus pendirian rumah ibadah di kalangan Kristen. Pada beberapa kasus pendirian atau penyalahgunaan rumah tinggal menjadi rumah ibadah banyak dilatarbelakangi oleh terjadinya konflik internal penganut Kristen tersebut. Misalnya dalam kasus gereja Bethel Tabernakel pimpinan pendeta Hadassah bermula dari konflik antara Hadassah dengan pengelola gereja lain. Perselisihan ini menjadikan komunitas Hadasah memisahkan diri dan membuat tempat ibadah sendiri.

Maraknya pendirian gereja di wilayah Jawa Barat sesungguhnya merupakan dampak lanjutan dari adanya konflik internal dalam agama Kristen itu sendiri. Para jemaat dalam satu gereja yang sama sering mengalami perselisihan yang berbuah pada perpecahan jemaat gereja tersebut. Perpecahan dalam satu gereja sudah lama dikenal dalam sejarah agama Kristen yang disebut sebagai 'skisma.' Kenyataan ini mengindikasikan tingginya potensi konflik internal dalam agama Kristen yang berakibat pada munculnya kelompok atau jemaat yang memisahkan dari gereja asalnya.

Konflik antar jemaat gereja salah satunya berakar pada kemunculan sekte-sekte dalam agama Kristen. Menurut Kepala Kantor Wilayah Kementerian Agama (Kakanwil Kemenag) Jawa Barat, H Saeroji, mengatakan pembangunan gereja kerap dibangun berdasarkan sekte. Menurutnya, kasus seperti itu memberi kesan bahwa setiap sekte ingin memiliki gereja sendiri. Inilah salah satu yang seringkali membuat masyarakat tidak nyaman dengan pembangunan gereja yang menjamur disekitar pemukiman mereka.

Dalam catatan Kemenag Provinsi Jawa Barat saat ini terdapat 350 sekte dalam Kristen Protestan. Jika semua sekte tersebut ingin mendirikan gerejanya masing-masing, maka hal tersebut akan memicu konflik yang lebih besar lagi. Kasus seperti ini misalnya tampak pada Gereja Batak yang pasti berbeda dengan Gereja Jawa, padahal masih dalam satu ajaran.
Penelitian CRCS (Cholil, dkk., 2010) tahun 2009 mencatat terdapat 18 kasus kekerasan yang dipicu sengketa pendirian rumah ibadah. Sedangkan tahun 2010 ini terdapat 39 kasus. Dengan cakupan wilayah data yang relatif sama, penelitian itu menunjukan bahwa kasus di seputar rumah ibadah pada tahun 2010 ini lebih banyak dibanding tahun sebelumnya. Dari 39 kasus seputar rumah ibadah, konflik atau ketegangan yang melibatkan konflik antarumat beragama masih mendominasi, yaitu 32 kasus (82\%). Sedangkan 4 kasus (10\%) melibatkan konflik internal umat beragama seperti internal umat muslim 1 kasus, internal umat Protestan 1 kasus, dan internal umat Katolik 1 kasus. Sejumlah 3 kasus (8\%) lain tidak bisa diidentifikasi.

Data tersebut menegaskan bahwa persoalan kerukunan tidak hanya melibatkan antara agamaagama yang berbeda, namun juga terjadi pada intra-umat beragama. Namun, angka kekerasan dan konflik yang melibatkan antar kelompok berbeda agama jauh lebih tinggi dengan 32 kasus atau sekitar $82 \%$. Sedangkan 4 kasus (10\%) melibatkan konflik internal umat beragama seperti internal umat Muslim 1 kasus, internal umat Protestan 1 kasus, dan internal umat Katolik 1 kasus.

Konflik di Jawa Barat dapat dijelaskan dengan membaca perubahan sosial kontemporer di wilayah ini, terutama pada wilayah-wilayah urban. Proses perpindahan penduduk yang tidak terkendali dan terkontrol dalam banyak kasus telah menjadi salah satu faktor yang dapat memicu konflik antar etnis dan berlanjut menjadi konflik antar pemeluk agama. Tingginya pertumbuhan penduduk perkotaan disebabkan oleh angka migrasi masuk ke kota besar selalu meningkat. Tingginya tingkat migrasi (kelompok kepentingan) disertai motivasi untuk maju, menyebabkan banyak ruang, waktu, dan sumber daya alam telah dikuasai oleh kelompok pendatang tanpa disadari dan dipedulikan oleh masyarakat lokal. Pada batas tertentu penduduk lokal terusik bahwa sejumlah sumber daya alam dan manusia telah diambil alih pendatang.

Kondisi demikian dapat menimbulkan pola hubungan sosial yang timpang (inequal) dan tidak seimbang antara penduduk pendatang dan penduduk lokal. Hubungan yang tidak seimbang merupakan potensi bagi munculnya konflik sosial.

\section{Profil Jaringan Kerja Antar Umat Beragama}

Jaringan Kerja Antar Umat Beragama (Jakatarub) merupakan aliansi dari berbagai 
komunitas keagamaan, budaya dan kelompok sosial yang ada di Jawa Barat. Jakatarub berdiri pada tahun 2001. Proses pendiriannya dimulai dari sebuah workshop di Pesantren Luhur Al-Wasilah, Kabupaten Garut pada tahun 2000 yang difasilitasi oleh INCRëS dan Madia. Workshop tersebut diselenggarakan sebagai upaya untuk membaca tantangan dan masa depan dialog antaragama dalam konteks kebudayaan di Jawa Barat. Para peserta yang berpartisipasi dalam acara waktu itu datang dari berbagai latar agama, kepercayaan, adat istiadat, tradisi, dan lingkungan yang berbeda dari beberapa daerah se-Jawa Barat.

Setelah pertemuan pertama yang diselenggarakan di pondok pesantren, peserta workshop melanjutkan pertemuan ke dua pada bulan april 2001 di Vihara Vipassana Graha Lembang Bandung. Pada acara tersebut dibicarakan tentang agama dan rekonsiliasi dengan cara menggali paradigma baru dalam beragama. Tema ini diangkat sebagai upaya untuk mendekonstruksi paradigma keberagamaan lama dan kemudian merekonstruksi paradigma baru dalam beragama.

Masih pada 2001 dilakukan pertemuan kembali untuk ketiga kalinya. Pertemuan ini difasilitasi oleh Gereja Katolik Buah Batu Bandung, tepatnya tanggal 12 Mei dan 30 Juni 2001. Pada pertemuan ketiga tersebut mulai dibicarakan tentang format atau wadah demi keberlangsungan kerja transformatif dialog antaragama, yang kemudian menjadi cikal bakal lahirnya Jakatarub. Dari beberapa diskusi dan pertemuan inilah lahir sebuah nama 'Jakatarub' [Jaringan Kerja Antar Umat Beragama. Sebuah nama yang di dalamnya bersemayam 'nilai' semangat yang selalu ingin berbuat. Sebuah nama yang ingin menebus harapan dan cita-cita kedamaian umat manusia dengan kesungguhan untuk melakukan sesuatu. Sebuah ikhtiar yang diidealisasikan untuk membawa kehidupan beragama ke arah yang lebih terbuka, santun, beradab, dan mampu turut menciptakan kedamaian sosial, keadilan manusia, dan kebersamaan dalam keragaman.

Sebagai sebuah jaringan lintas agama dan kelompok Jakatarub menjadi simpul bagi bertemunya berbagai kelompok agama, tradisi dan kelompok sosial yang berbeda untuk melakukan dialog, merayakan perbedaan dan mengkampanyekan pentingnya sikap toleransi di Bandung secara khusus dan umumnya di wilayah Jawa Barat. Dalam kiprahnya, jaringan ini sudah menyelenggarakan berbagai acara dalam rangka mewujudkan masyarakat yang menghargai perbedaan.

Secara garis besar program yang diusung Jakatarub terbagi menjadi tiga pilar, yaitu pertama, pilar teologi, kedua, pilar kebudayaan, dan ketiga, pilar media. Pilar teologi diwujudkan dalam berbagai bentuk dialog, seminar, diskusi dan kunjungan ke berbagai komunitas agama yang ada di Bandung. Melalui pilar teologi ini keluarga besar Jakatarub diajak untuk belajar memahami dan mengalami perbedaan doktrin agama yang berbeda, mendialogkan dan merefleksikannya sebagai bagian dari kehidupan nyata. Cara ini dilakukan sebagai upaya menghilangkan prasangka negatif (prejudice) tentang kelompok agama di luar agama yang mereka yakini. Aspek teologi sengaja dibicarakan secara terbuka di lingkungan keluarga besar Jakatarub untuk memberikan kesempatan memahami keragaman keyakinan orang lain, tanpa harus merasa takut bahwa mereka akan diajak untuk berpindah pada keyakinan orang lain tersebut.

Pilar kebudayaan diselenggarakan dalam beragam event kebudayaan baik kebudayaan populer maupun yang tradisional. Pada beberapa kesempatan acara kebudayaan terselenggara dengan menggandeng berbagai komunitas kebudayaan dan komunitas anak muda Bandung. Misalnya pada penyelenggaraan event tahunan seperti peringatan ulang tahun Konferensi Asia Afrika (KAA) dimana Jakatarub menjadi bagian dalam rangka promosi perdamaian dan nilai toleransi.

Pada kesempatan lain Jakatarub menyelenggarakan acara nonton film bareng yang bertemakan perdamaian dan toleransi. Di antara film yang pernah ditayangkan misalnya berjudul Mata Tertutup yang merupakan produksi Garin Nugroho dengan Maarif Institute Jakarta.

Pilar media menyadari pentingnya informasi, Jakatarub juga mendesain program dalam bidang media. Pilar ini diorientasikan sebagai alat untuk mempublikasikan eksistensi lembaga dan juga mensosialisaikan program-program yang dilakukan. Pada pilar media ini dipilih beberapa program yang populer dan dapat menjangkau khalayak anak muda terutama dengan memanfaatkan media online seperti website, blog, mailist dan lain-lain.

Penggunaan media online cukup efektif dalam medesiminasi gagasan dan membuka ruang dialog yanglebihterbukadikalangananakmudadiBandung. 
Pilar ini juga diharapkan dapat menjadi alternatif bahkan tandingan di tengah membludaknya media online yang mengkampanyekan kebencian terhadap kelompok agama yang berbeda.

Secara spesifik program kegiatan Jakatarub lebih banyak diarahkan pada segmen anak muda. Pilihan ini dilandasi pertimbangan bahwa selama ini anak muda justru yang menjadi sasaran dari rekruitmen untuk menjadi pelaku konflik. Pada sejumlah kasus teror dan konflik keagamaan, pelakunya datang dari kalangan anak muda. Selain itu, disadari bahwa anak muda dan remaja merupakan kelompok usia yang potensial untuk diarahkan menjadi pelaku perdamaian atau sebaliknya menjadi pelaku konflik. Selain alasan tersebut, pilihan pada segmen kalangan anak muda juga disebabkan karena jumlah angkatan muda di wilayah Bandung cukup tinggi. Karena itu, sasaran dari program perdamaian dan penyebaran nilainilai toleransi lebih diarahkan pada kelompok usia ini. Dengan alasan itu pula maka program yang didesain Jakatarub bergaya khas anak muda dengan kesan yang santai, menyenangkan, terbuka tetapi tetap memiliki makna. Lebih dari itu, keluarga besar Jakatarub sendiri diprakarsai dan dimotori anakanak muda. Dengan demikian menjadi lebih mudah dalam menyampaikan pesan-pesan toleransi dan perdamaian kepada mereka.

\section{Manajemen konflik: Jakatarub sebagai Jaringan Kewargaan}

Relasi yang kondusif dalam masyarakat bergantung pada masyarakatnya sendiri. Bagaimanapun, masyarakat merupakan bagian dari setiap dinamika dalam kehidupan mereka sendiri. Dalam banyak kasus, munculnya konflik maupun terjadinya perdamaian terkait dengan kesiapan masyarakat berkaitan dalam mengelola setiap potensi dalam masyarakat ke arah damai atau konflik. Karena itu sangat penting untuk melihat bagaimana mekanisme yang dikembangkan oleh berbagai komunitas dalam mengelola perbedaan dan dinamika sosial agar tidak menjadi sumber konflik.

Pada bagian ini dieksplorasi bagaimana pengalaman komunitas Jaringan Kerja Antar Umat Beragama (Jakatarub) melakukan pengelolaan keragaman, perbedaan, dan dinamika sosial keagamaan yang ada di Bandung dan Jawa Barat secara umum agar tidak menjadi konflik.

Komunitas Jakatarub merupakan aliansi dari berbagai komunitas keagamaan dan sosial yang bermukim di Bandung dan sekitarnya. Pada komunitas ini tergabung pemeluk agama Islam, Protestan, Katholik, Konghucu, Hindu, Budha dan beberapa keyakinan lokal. Di samping itu tergabung juga kelompok yang berbasis kebudayaan Sunda. Dengan berbagai latar belakang seperti itu, komunitas ini berusaha untuk menjadi simpul bagi perbedaan etnik, agama dan kelompok sosial.

Komunitas Jakatarub berfungsi sebagai wadah untuk berkomunikasi antar kelompok yang berbeda-beda. Melalui wadah ini perbedaan yang bagi sebagian orang menjadi petaka dan sumber pertikaian, dapat dirajut menjadi sumber kekuatan dalam masyarakat. Hal ini yang disebut sebagai upaya menjadikan perbedaan sebagai driving force untuk membangun kekuatan yang positif dan kontributif bagi masyarakat. Dalam komunitas Jakatarub perbedaan diposisikan sebagai fondasi bagi terjadinya komunikasi.

Kiprah komunitas Jakatarub di tengah masyarakat bandung berfungsi sebagai jejaring antar warga (civic network). Dalam kajian mengenai konflik etnik, pendekatan civil society atau civic networks (jejaring antarwarga) dikembangkan oleh Ashutosh Varshney (2002). Varshney menggunakan pendekatan ini untuk memahamai konflik antara Hindu dan Muslim di India. Cara ini memiliki relevansi untuk membaca fenomena konflik komunal yang terjadi di Indonesia.

Varshney (2002: 3-4) membagi jejaring keterlibatan antarwarga (networks of civic engagement) menjadi dua bentuk: pertama, bentuk keterlibatan yang bersifat asosiasional; kedua, bentuk hubungan sehari-hari (everyday forms of civic engagement), yang disebutnya juga sebagai bentuk hubungan 'quotidian'. Menurutnya, kedua bentuk keterlibatan antarwarga itu, jika kuat, dapat mendukung terwujudnya perdamaian. Sebaliknya, jika hubungan itu lemah atau tidak ada sama sekali, maka akan terbuka peluang bagi terjadinya kekerasan komunal. Dari kedua bentuk hubungan antarwarga itu, bentuk hubungan asosiasional lebih kokoh dibandingkan bentuk keterlibatan seharihari, khususnya ketika masyarakat dihadapkan dengan "goncangan dari luar" (exogenous shock), seperti rumor atau upaya kalangan politisi untuk memanfaatkan polarisasi komunitas-komunitas etnis.

Bagaimana kaitan antara ikatan antarwarga (civic ties) dan konflik dapat dimengerti?. Pertama, 
menurut Varshney (2002: 46-47), kontak yang sudah terjalin antar anggota dari komunitas-komunitas yang berbeda memungkinkan berlangsungnya komunikasi di antara mereka untuk meredakan ketegangan dan mencegah terjadinya kekerasan tatkala muncul ketegangan akibat gangguan dari luar, baik berupa terjadinya kerusuhan di wilayah lain yang berdekatan, peristiwa kekerasan di lokasi yang berjauhan namun terekam dalam laporan media massa, rumor yang ditiupkan oleh para politisi yang berusaha memanfaatkan ketegangan tersebut, ataupun tindakan-tindakan provokasi oleh berbagai pihak. Kedua, di tempat-tempat di mana keterlibatan antarwarga sudah terjalin kuat, terutama di wilayah perkotaan, baik dalam bentuk asosiasi maupun dalam bentuk keterlibatan seharihari yang bersifat informal, landasan perdamaian menjadi lebih kuat. Di tempat-tempat semacam itu, upaya para politisi, yang secara teori, berusaha memanfaatkan polarisasi etnis tersebut akan sulit untuk memperlebar jurang perbedaan tersebut, menyebarkan rasa kebencian dan permusuhan, serta memicu kekerasan.

Keberadaan komunitas dapat berfungsi sebagai jejaring warga yang terfragmentasi dalam berbagai kepentingan dan identitas agama dan kelompok. Dengan adanya jejaring tersebut masyarakat dipertemukan dalam ruang kebersamaan. Proses komunikasi antar berbagai elemen dalam komunitas ini diwujudkan dalam berbagai kegiatan. Ada tiga pilar utama yang diupayakan komunitas Jakatarub dalam rangka mengelola perbedaan dan keragaman pada masyarakat Bandung, Jawa Barat.

Pilar pertama, teologi. Salah satu faktor yang sering dianggap masyarakat umum sebagai pemicu konflik adalah perbedaan agama. Konflik yang dilatarbelakangi perbedaan agama dapat terjadi antar kelompok agama yang berbeda maupun intra komunitas agama. Artinya dengan semakin heterogen pemeluk agama dalam sebuah masyarakat maka semakin tinggi pula potensi ke arah terjadinya konflik. Menyadari hal demikian, Jakartarub menjadikan aspek teologi sebagai prioritas dalam mengelola perbedaan yang ada pada masyarakat Bandung dan Jawa Barat. Di kota yang dijuluki Paris van Java ini bermukim berbagai kelompok agama. Eksistensi kelompok agama yang sudah ada sejak masa kolonial Belanda menjadikan Bandung sebagai tempat bermukim. Hal ini dapat dilihat dari adanya sejumlah gereja tua yang berdiri berdampingan dengan masjid maupun kantor organisasi Islam. Misalnya posisi masjid dan kantor Persatuan Islam (Persis) yang berlokasi dekat dengan beberapa gereja. Di wilayah Bandung juga bermukim beberapa komunitas keagamaan, dari komunitas agama mainstream seperti Nahdahtul Ulama, Muhammadiyah, Persatuan Islam, hingga yang dianggap minoritas seperti Syiah, Ahmadiyah serta beberapa organisasi keagamaan yang dikenal berhaluan keras (hardliner) seperti FUUI, Laskar Sabilillah, FPI, Gerakan Islam Reformis (Garis) juga kelompok Islam transnasional seperti Hizbut Tahrir.

Keragaman aliansi dan watak organisasi keagamaan di Bandung sebagaimana dijelaskan tadi telah memunculkan ketegangan hubungan antara komuitas keagamaan. Relasi antar komunitas keagamaan ini memposisikan beberapa komunitas keagamaan sebagai minoritas seperti Ahmadiyah dan Syiah terhadap kelompok yang mengklaim sebagai representasi dari ahlusunnah wal jamaah. Peran yang dilakukan oleh Jakatarub dalam ketegangan hubungan komunitas ini adalah dengan berpegang pada hak-hak dasar setiap orang dan kelompok. Jakatarub tetap konsisten untuk mengkampanyekan nilai toleransi dan penghargaan terhadap hak-hak warga negara. Dalam konteks hubungan antar kelompok agama di Bandung, seringkali yang menjadi korban adalah kelompok minoritas seperti Syiah, Ahmadiyah dan aliran keagamaan yang dianggap sesat. Dalam kontek itu, peran yang dijalankan komunitas Jakatarub adalah menginisiasi terbentuknya forum dialog antara kelompok agar perbedaan tersebut tidak semakin meruncing. Prinsip dasar dalam kegiatan pengelolaan konflik yang dilakukan Jakatarub adalah dengan tetap mengedepankan nilai-nilai universal seperti toleransi, menghormati hak orang lain dan perdamaian. Dalam kasus perseteruan antara kelompok FUUI yang mengklaim sebagai representasi Sunni dan kemudian menganggap Syiah sebagai ajaran sesat, komunitas Jakatarub berada pada kelompok yang terdiskriminasi, dalam hal ini Ahmadiyah maupun kelompok Syiah. Alasan ini yang mendorong keluarga Jakatarub berpartisipasi dalam proses deklarasi berdirinya ormas Majelis Ukhuwah Sunni-Syiah di Jawa Barat (Muhsin).

Keberpihakan ini tidak didasarkan pada identitas ke Ahmadiyahan dan ke Syiahannya, melainkan pada penegakan nilai-nilai toleransi, pluraisme dan penghormatan terhadap warga 
negara. Dalam pandangan komunitas Jakatarub, kemunculan ormas Majelis Ukhuwah Sunni Syiah merupakan respon terhadap menguatnya sikap diskriminatif dan pengadilan keyakinan oleh sebagian kelompok keagamaan lain, seperti FUUI, Gerakan Islam Reformis (Garis), dan lain-lain.

Dalam konteks masyarakat Bandung yang mejemuk, mengadakan dialog keagamaan merupakan sesutau yang niscaya. Terutama bagi kelompok-kelompok keagamaan yang berbedabeda. Peran yang dilakukan Jakatarub dalam rangka mengelola perbedaan tadi adalah dengan terus menghadirkan forum-forum dialog. Dalam hal ini dialog keagamaan merupakan bentuk komunikasi yang efektif dalam rangka menghilangkan prasangka dari masing-masing kelompok agama yang selama ini cenderung ekslusif. Upaya dialog keagamaan yang dilakukan Jakatarub melibatkan berbagai kelompok agama yang ada di Bandung. Ada beberapa upaya dialog yang dilakukan. Jika mengacu pada model dialog sebagaimana dikategorisasikan Sumartana (tanpa tahun) maka apa yang dikerjakan Jakatarub juga menyasar pada model dialog seperti dialog hidup, dialog aksi, dialog teologis, dan dialog pengalaman keagamaan.

Pertama, melalui dialog hidup, setiap komunitas yang terlibat dalam dialog ini, mereka berusaha membuka hidup setiap komunitas keagamaan untuk melihat realitas lain dalam pengalaman yang berbeda sebagai sesama manusia. Dengan meletakan kesamaan pada realitas sebagai sesama manusia, maka posisi orang dan kelompok yang berbed menjadi sejajar. Sementara yang dimaksud dengan dialog aksi, adalah segala ikhtiar untuk bekerja sama mengatasi pembatasanpembatasan yang menghalangi kita untuk hidup secara bebas dan manusiawi. Beberapa acara aksi sudah dilakukan Jakatarub dengan melibatkan beberapa kelompok agama, misalnya dengan mengadakan kerja sosial, kegiatan amal dan kampanye perdamaian.

Kemudian dalam dialog teologis pimpinan dari setiap kelompok agama membicarakan warisanwarisan keagamaan dengan nilai-nilainya agar dapat memahami dengan lebih dalam dan menghargai lebih tulus. Dialog pengalaman keagamaan mereka yang berakar pada tradisi-tradisi agama masingmasing. Mereka menegaskan bahwa dialog agama, bukan dimaksudkan untuk membuat pihak yang diajak dialog mengikuti iman kelompok lain, tidak ada proses dakwah, yang diharapkan dalam kegiatan model ini justru untuk membuat antara partisipan dialog memahami sisi-sisi kebenaran masing-masing dengan mengenal orang lain, dan tidak dengan kecurigaan.

Peran seperti ini dijalankan oleh Jakatarub untuk memberikan ruang bagi setiap kelompok yang berbeda dapat saling bersilaturahmi dan saling mendengarkan. Dengan adanya ruang dialog maka setiap kelompok mendapat kesempatan untuk menyampaikan aspirasi dan tidak dihakimi secara sepihak.

Forum dialog dilakukan selama ini bertujuan agar dapat menyentuh dua hal pokok yaitu: menghidupkan suatu kesadaran baru tentang cara beragama dengan melihat cara beragama orang lain. Seringkali dalam cara masyarakat beragama tidak mau membuka mata terhadap keyakinan orang lain dan melakukan klaim buta. Jakatarub memfasilitasi ini misalnya dengan mengajak para anggota dalam komunitas ini mengunjungi rumah ibadah kelompok agama yang berbeda dengan keyakinannya dan juga mengikuti ritual keagamaan sebagai bagian dalam menginternalisasi pengalaman. Melalui program seperti ini juga memberikan penegasan bahwa prejudice selama ini tentang sentimen anti agama tertentu tidak terbukti. Hal ini misalnya dilakukan dalam sebuah program beberapa mahasiswa Universitas Islam Negeri Bandung yang berkunjung ke salah satu gereja di Bandung. Kunjungan tersebut selain mengenalkan para mahasiswa muslim pada realitas yang sebenarnya tentang perbedaan, tetapi sekaligus menjadi undangan pada pihak komunitas Kristiani untuk juga membalas kunjungan tersebut pada komunitas muslim.

Kegiatan kunjungan seperti ini merupakan dialog antar kelompok yang efektif. Dialog mengarah kepada suatu pemahaman yang otentik mengenai orang lain, tanpa sikap meremehkan dan apalagi mendistorsikan keyakinan-keyakinan yang mereka yakini tersebut. Bertemunya kelompok seperti itu justru suatu percakapan yang sungguhsungguh dialogis yang bisa menjadi langkah untuk memperoleh "mutual enrichment" bagi setiap penghayatan iman yang berbeda-beda.

Dialog juga dilakukan untuk mengarahkan sebanyak mungkin komunitas keagamaan dan kelompok sosial kepada kerjasama untuk memecahkan persoalan kemanusiaan bersama yang ada di masyarakat. Dengan percakapan dialogis juga 
merupakan suatu kesempatan untuk menggalang kerja sama antaragama untuk memecahkan masalah-masalah kemanusiaan yang nyata di masyarakat. Keprihatinan agama-agama ini akan merupakan suatu kekuatan baru bagi kemanusiaan untuk menanggulangi eskalasi persoalan yang formatnya memang bersifat lintas agama.

Jika, dialog keagamaan dapat dilakukan secara terus menerus dilakukan, maka berbagai konflik yang berbasis agama akan sulit terjadi. Sebaliknya, dengan adanya dialog keagamaan justeru akan memperkokoh keutuhan dalam masyarakat yang heterogen, dan selanjutnya menumbuhkan saling pemahaman yang baik tentang makna keragaman.

Apa yang selama ini dijalankan Jakatarub dengan dialog adalah cara untuk melintasi batas kecurigaan antara kelompok agama, dengan demikian proses dialog tersebut akan memberikan bagi tumbuhnya relasi atau hubungan antar kelompok keagamaan yang produktif.

Selain dialog keagamaan, peran kedua yang dilakukan Jakatarub berada pada ranah kebudayaan. Di samping agama, ranah kebudayaan dapat menjadi alternatif saat channel teologis tersumbat. Pada banyak kasus dialog tidak terjadi karena sudah sejak awal dibawa pada wilayah teologis. Sebaiknya, pengelolaan terhadap perbedaan agama dapat diantisipasi pada tahap pra-konflik sebagai upaya pencegahan. Namun seringkali sentimen agama dan kelompok paham keagamaan sulit dipertemukan, karena itu, kebudayaan dapat menjadi pintu masuk yang lain bagi terciptanya komunikasi antar kelompok dalam masyarakat. Dalam pemahaman masyarakat Indonesia, atau Muslim secara khusus, agama dan kebudayaan merupakan dua hal yang berbeda. Budaya dianggap sebagai hasil kreasi masyarakat dan bersifat profan. Sementara agama adalah sesuatu yang datang dari Tuhan, karena itu bersifat sakral (suci). Dengan pemahaman ini, konflik yang bernuansa agama mendapat bobot emosional yang kuat karena dianggap suci. Tetapi dalam agama sering berhadapan dengan adanya klaim kebenaran antar kelompok, karena itu sering mengalami kebuntuan dalam resolusi konflik. Dalam kondisi seperti itu, kebudayaan dapat dijadikan alternatif atau bahkan pelengkap dalam mengelola konflik.

Kebudayaan dijadikan saluran dalam proses pengelolaan konflik karena kebudayaan tidak menghakimi, tidak menilai antara benar atau salah.
Berbasiskan pada keyakinan tersebut, Jakatarub memanfaatkan peristiwa kebudayaan sebagai simpul mempertemukan berbagai kelompok yang berpotensi akan mengalami konflik. Ada beberapa kegiatan kebudayaan yang rutin diselengarakan di Bandung, dari festival kebudayaan tradisional hingga yang kreatif kontemporer. Jakatarub terlibat dalam kegiatan tahunan peringatan Konferensi Asia Afrika (KAA). Kegiatan ini melibatkan lintas kelompok.

Kegiatan seperti ini dapat menjadi pintu masuk dalam mengkampanyekan nilai toleransi, pluralisme dan penghormatan terhadap hak-hak asasi manusia. Kegiatan kebudayaan juga menjadi media bertemunya kelompok-kelompok yang selama ini tersegregasi karena perbedaan.

Selain dua fokus wilayah yang dikelola tadi, Jakatarub juga memanfaatkan media sebagai wahana dalam mengelola hubungan antar kelompok di Bandung. Mereka menyebut media sebagai pilar ketiga dalam menjaga perdamaian di Bandung. Program yang dilakukan lebih pada memberi makna dan dimensi lain pada pertumbuhan media massa yang sangat pesat. Sejauh ini, belum banyak yang dikerjakan dan masih sebatas pada pengelolaan media on line, seperti website, blog, group dialog, milist, dan lain-lain. Pilihan ini didasarkan pada popularitas media on line terutama dikalangan anak muda kota. Penggunaan media online yang mudah dan murah juga menjadi alasan lain bagi Jakatarub memilih mengembangkan perannya di media on line.

Sisi strategis media massa adalah dalam rangka penyebaran gagasan perdamaian, toleransi dan juga memeperkenalkan komunitas Jakatarub pada khalayak yang lebih luas. Sebagai komunitas yang berbasis di kota dan anak muda, media memainkan peran yang penting untuk mengkampanyekan perdamaian. Kehadiran media-media yang damai juga dapat mengimbangi publikasi yang besar dari komunitas keagamaan yang intoleran dan cenderung menyulut permusuhan.

Dari ketiga hal (teologi, kebudayaan, dan media) tadi, manajemen konflik yang dilakukan Jakatarub lebih pada upaya mengantisipasi atau pencegahan agara faktor-faktor seperti perbedaan agama, kelompok sosial, jumlah penduduk yang besar, sektor ekonomi yang terbatas dan juga heterogenitas dalam masyarakat Bandung tidak mengarah pada konflik. Yang dilakukan Jakatarub 
adalah menyediakan ruang bagi komunikasi searah, sejajar, terbuka, dan saling menghormati sebagai sesama warga Bandung dan juga Indonesia. Berbagai kelompok tersebut dapat bertemu karena mereka dijembatani dengan saling memahami dan membuka diri terhadap kelompok agama lain, dan juga adanya prinsip kebudayaan pada masyarakat Bandung atau Sunda pada umumnya yang silih asah, silih asih dan silih asuh. Prinsip tersebut yang hendak direvitalisasi oleh komunitas ini sebagai nilai yang ada dalam tradisi masyarakat lokal Bandung.

\section{PENUTUP}

Sumber potensi konflik bernuansa keagamaan di wilayah Jawa Barat secara umum dapat dikelompokan pada dua hal. Pertama, adanya warisan ideologi gerakan Darul Islam/Tentara Islam Indonesia (DI/TII). Ideologi ini bermetamorfosis dalam berbagai aspirasi sebagian kelompok di Jawa Barat untuk menerapkan syariat Islam, atau dalam konteks yang lebih halus adalah dengan bermunculannya Peraturan Daerah (Perda) syariah yang lebih jauh menjadi legitimasi bagi kelompok tertentu melakukan kekerasan pada kelompok yang dinilai tidak sesuai syariah. Faktor kedua, sumber potensi konflik berkembang seiring dengan perubahan sosial dalam masyarakat Jawa Barat, terutama pada daerah yang berdekatan dengan ibu kota. Urbanisasi memberi pengaruh pada dinamika sosial keagamaan di wilayah ini. Ketiga, perubahan sosial terutama urbanisasi telah menjadikan beberapa daerah menjadi wilayah yang sangat heterogen, baik agama, etnik dan juga budaya.

Model pengelolaan (manajemen) konflik bernuansa keagamaan yang dilakukan di Jawa Barat, terutama di Bandung, adalah dengan munculnya komunitas jejaring warga (civic network) seperti Jaringan Kerja Antar Umat Beragama. Komunits seperti ini berperan sebagai simpul bagi bertemunya berbagai kelompok yang berbeda-beda. Kehadiran jejaring warga, seperti Jakatarub merupakan alternatif di tengah hilangnya ruang-ruang bagi interaksi warga yang dulu terwadahi dalam hubungan komunal.

Ada tiga pendekatan yang dilakukan Jakatarub, yakni pendekatan dialog teologis, partisipasi dalam kebudayaan, dan pengembangan media sebagai wahana perdamaian. Paradigma penanganan konflik yang sentralistik, hegemonik serta reaktif menyebabkan konflik yang ada semakin berkepanjangan dan meluas, seperti yang selama ini diterapkan. Kalaupun terjadi penyelesaian masih cenderung bersifat sementara, dipermukaan saja, karena kesepakatan damai seringkali tidak ditepati. Oleh karena itu diperlukan pola penanganan konflik yang berbasis pada akar persoalan serta dicegah dengan memanfaatkan kearifan lokal yang tersedia.

Menyadari hal itu perlu keterlibatan akademisi, tokoh masyarakat baik yang mewakili dirinya atau representasi kelembagaan lokal untuk terus menggagas dan mendiskusikan pembentukan sistem yang secara efektif dapat menangani konflik sosial keagamaan di Indonesia. Jakatarub merupakan salah satu lembaga lokal yang dapat diposisikan sebagai media alternatif dalam ruang diskusi dan perdamaian di tengah maraknya konflik sosial keagamaan. Komunits seperti ini berperan sebagai simpul bagi bertemunya berbagai kelompok yang berbeda-beda.

\section{UCAPAN TERIMA KASIH}

Tulisan ini berasal dari hasil penelitian atas anggaran DIPA Balai Litbang Agama Jakarta di tahun 2013. Oleh karena itu, penulis mengucapkan terima kasih kepada pimpinan lembaga tersebut yang memberikan kesempatan kepada penulis untuk melakukan penelitian ini. Penulis juga sampaikan terima kasih kepada seluruh narasumber yang diwawancarai oleh penulis dan pihak-pihak yang memberikan bantuannya, baik dalam proses penelitian maupun dalam penulisan artikel ini.

\section{DAFTAR PUSTAKA}

Amirrachman, Alpha (ed). 2007. Revitalisasi Kearifan Lokal: Studi Resolusi Konflik Di Kalimantan Barat, Maluku Dan Poso. Jakarta: International Center for Islam and Pluralism: European Commission.

Cholil, Suhadi, dkk. 2010. Laporan Tahunan Kehidupan Beragama di Indonesia Tahun 2009. Yogyakarta: Center for Religious and Cross Cultural Studies, UGM.

Darban, A.Adarby. 2007. "Mengungkap Biografi Sekarmaji Marijan Kartosuwiryo" dalam Jurnal Humaniora XIX No. 2 Tahun 2007. Yogyakarta: Fakultas Ilmu Budaya Universitas Gadjah Mada.

Farida, Anik, dkk. 2008. Laporan Penelitian: Pola Konflik Keagamaan Tahun 2004-2007 di 10 Provinsi di Wilayah Indonesia Bagian Barat. Jakarta: Balai Litbang Agama Jakarta.

Farida, Anik. 2011. Laporan Penelitian: Sistem Siaga 
Dini pada Konflik Komunal di Jawa Barat. Jakarta: Balai Litbang Agama Jakarta.

Peraturan Bersama Menteri (PBM No 9 dan 8 tahun 2006 tentang Pendirian Rumah Ibadat.

Rai, Wayan. 2011. "Manajemen Konflik Sosial sebagai Prakondisi Masyarakat Ipteks" Ngayah, 2/1/2011.

Sumartana, Th. Dkk. Tt. Menuju Dialog antar Iman. Seri Dian 1 Tahun I. Yogyakarta: Dian/ Interfidei.

Tim Peneliti INSEP. 2007. Paham dan Pemikiran
Keagamaan dalam Perspektif Hermenitika di Ma,had al-Zaitun, Hergeulis, Indramayu, Jawa Barat. Jakarta: Yayasan INSEP

Van Bruinessen, Martin. 2002. "Genealogies of Islamic Radicalism in Post-Soeharto Indonesia”. South East Asia Research. 10/2

Varshney, Ashutosh. 2002. Konflik Etnis dan Peran Masyarakat Sipil: Pengalaman India. Diterjemahkan oleh Siti Aisyah, Ayu Diasti dan Sri Murniati. Jakarta: Balai Litbang Agama Jakarta. 